\section{9}

$\frac{18}{2 \cdot 12} / 87852$

.

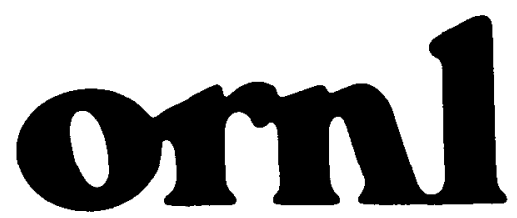

OAK RIDGE NATIONAL LABORATORY

MARTIN MARIETRA

T. M. Besmann

\title{
Assessment of Ceramic Composites for Multimegawatt Space Nuclear Power Systems
}

\section{DO NOT RICROFILN COVER}

OPERATED BY

MARTIN MARIETTA ENERGY SYSTEMS, INC.

FOR THE UNITED STATES 


\section{DISCLAIMER}

This report was prepared as an account of work sponsored by an agency of the United States Government. Neither the United States Government nor any agency Thereof, nor any of their employees, makes any warranty, express or implied, or assumes any legal liability or responsibility for the accuracy, completeness, or usefulness of any information, apparatus, product, or process disclosed, or represents that its use would not infringe privately owned rights. Reference herein to any specific commercial product, process, or service by trade name, trademark, manufacturer, or otherwise does not necessarily constitute or imply its endorsement, recommendation, or favoring by the United States Government or any agency thereof. The views and opinions of authors expressed herein do not necessarily state or reflect those of the United States Government or any agency thereof. 


\section{DISCLAIMER}

Portions of this document may be illegible in electronic image products. Images are produced from the best available original document. 

Printed in the United States of America. Available from National Technical Information Service
U.S. Department of Commerce
5285 Port Royal Road, Springfield, Virginıa 22161
NTIS price codes-Printed Copy: A03; Microfiche A01

This report was prepared as an account of work sponsored by an agency of the United States Government. Neither the United States Government nor any agency thereof, nor any of their employees, makes any warranty, express or implied, or assumes any legal liability or responsubility for the accuracy, completeness, or usefulness of any information, apparatus, product, or process disclosed, or represents that its use would not infringe privately owned rights Reference herein to any specific commercıal product, process, or service by trade name, trademark, manufacturer, or otherwise, does not necessarily constitute or imply its endorsement, recommendation, or favoring by the United States Government or any agency thereof The views and opinions of authors expressed herein do not necessarily state or reflect those of the United States Government or any agency thereot

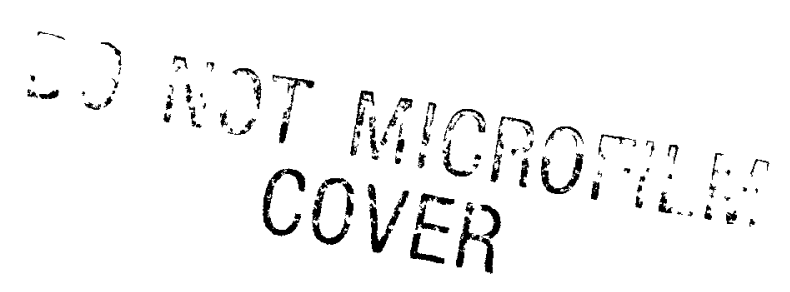


DE87 005272

METALS AND CERAMICS DIVISION

\title{
ASSESSMENT OF CERAMIC COMPOSITES FOR MULTIMEGAWATT SPACE NUCLEAR POWER SYSTEMS
}

T. M. Besmann

Date Published: December 1986

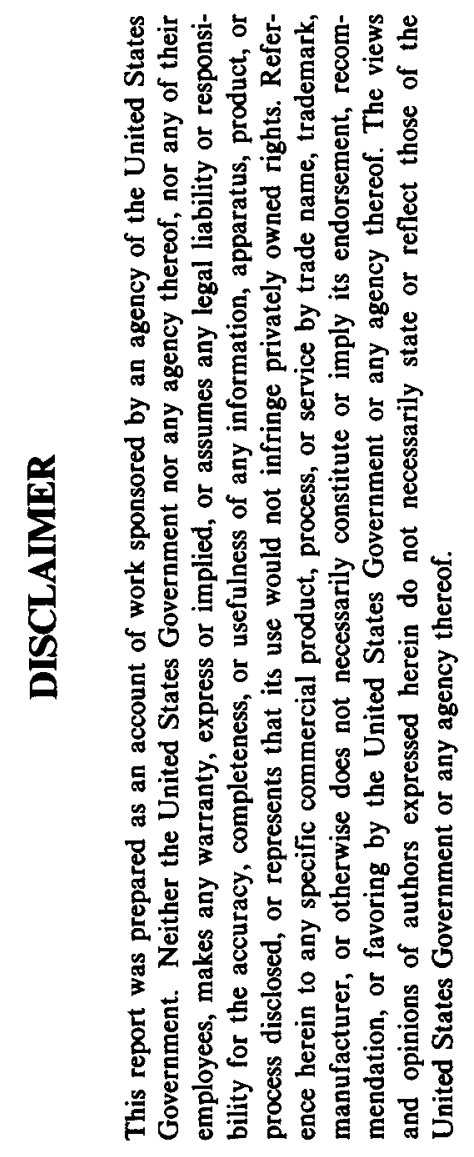

NOTICE: This document contains information of a preliminary nature. It is subject to revision or correction and therefore does not represent a final report.

\author{
Prepared for \\ Division of Defense Energy Projects \\ U.S. Department of Energy \\ Prepared by the \\ OAK RIDGE NATIONAL LABORATORY \\ Oak Ridge, Tennessee 37831 \\ operated by \\ MARTIN MARIETTA ENERGY SYSTEMS, INC. \\ for the \\ U.S. DEPARTMENT OF ENERGY \\ under contract DE-AC05-840R21400
}


page blank

ii 


\section{CONTENTS}

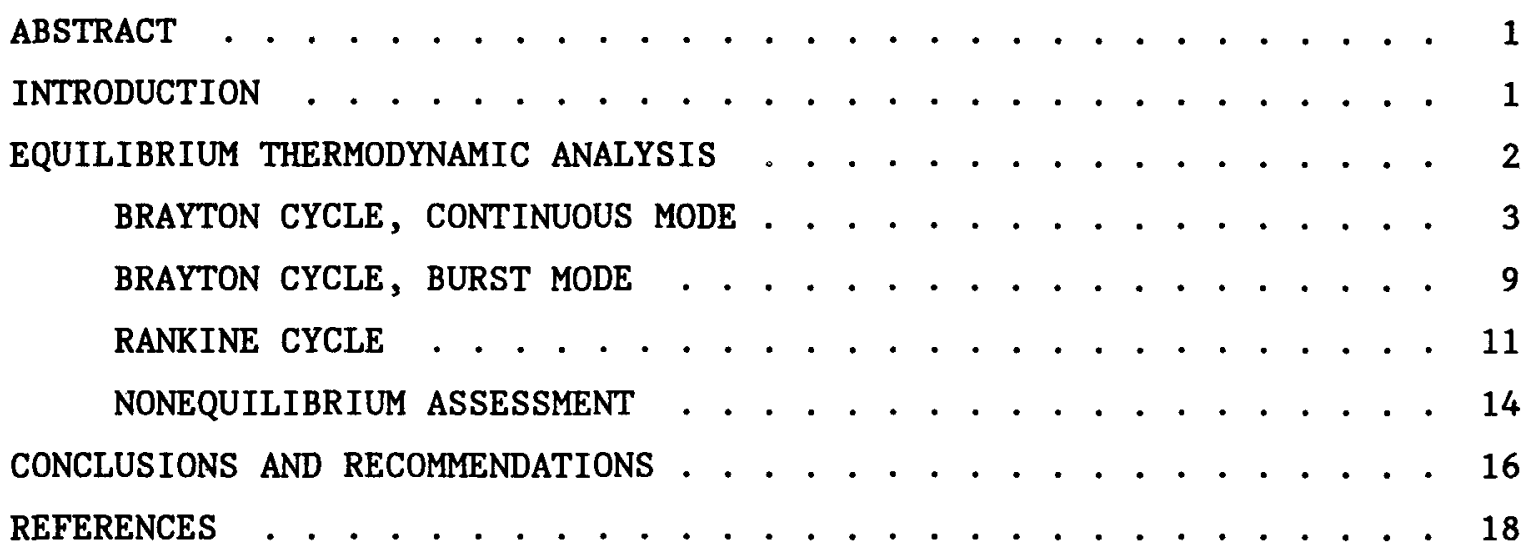




\title{
ASSESSMENT OF CERAMIC COMPOSITES FOR MULTIMEGAWATT SPACE NUCLEAR POWER SYSTEMS*
}

T. M. Besmann

\begin{abstract}
'
A calculational thermodynamic equilibrium analysis of the compatibility of ceramic-ceramic composites and a nonequilibrium assessment based on the literature of their use in proposed multimegawatt space nuclear power systems was performed. The five candidate composites included $\mathrm{Al}_{2} \mathrm{O}_{3}$-reinforced $\mathrm{Al}_{2} \mathrm{O}_{3}$, SiC-whisker-toughened $\mathrm{Al}_{2} \mathrm{O}_{3}, \mathrm{SiC}$-whisker-toughened $\mathrm{Si}_{3} \mathrm{~N}_{4}$, SiC-fiber-reinforced $\mathrm{ZrC}$, and carbon-fiber-reinforced $\mathrm{ZrC}$. The reactor concepts included Brayton cycle (continuous and burst mode) and Rankine cycle. It was determined that $\mathrm{Al}_{2} \mathrm{O}_{3}$-reinforced $\mathrm{Al}_{2} \mathrm{O}_{3}$ and carbon-fiber-reinforced $\mathrm{ZrC}$ are compatible in the Brayton-cycle continuous-mode system and that $\mathrm{Al}_{2} \mathrm{O}_{3}$-reinforced $\mathrm{Al}_{2} \mathrm{O}_{3}$, SiC-fiber-reinforced $\mathrm{ZrC}$, and carbon-fiber-reinforced $\mathrm{ZrC}$ are compatible in the Rankine-cycle system. None of the candidate ceramic composite systems was likely to be sufficiently stable under Brayton-cycle burst-mode conditions.
\end{abstract}

\section{INTRODUCTION}

Proposed multimegawatt (MMW) space nuclear power systems are designed to operate at high temperatures that are unprecedented and, in some designs, with potentially corrosive working fluids. These temperatures, levels of stress, and hostile environments may be outside the capability of refractory alloys, so designers are interestd in the use of ceramic composites as structural materials.

Two MMW space reactor power cycles are under consideration, a Brayton and a Rankine cycle. The Brayton cycle is envisioned as using inert gas as the working fluid during continuous operation with a peak temperature of $1500 \mathrm{~K}$, and hydrogen as the working fluid for short-duration (30-min) high-power operation at a temperature of $2500 \mathrm{~K}$. The Rankine-cycle system uses potassium liquid and vapor as the working fluid with a peak temperature of $1450 \mathrm{~K}$.

*Research sponsored by the Division of Defense Energy Projects, U.S. Department of Energy, under contract DE-AC05-840R21400 with Martin Marietta Energy Systems, Inc. 
The object of this assessment is to determine the applicability of several candidate ceramic composites to the proposed MMW space power systems. Five ceramic composites have been identified as potentially possessing the necessary high-temperature stability and mechanical properties. These include two previously developed materials - SiCwhisker-reinforced $\mathrm{Al}_{2} \mathrm{O}_{3}$ and $\mathrm{SiC}$-whisker-reinforced $\mathrm{Si}_{3} \mathrm{~N}_{4}$ - and three speculative materials - carbon-fiber-reinforced $\mathrm{ZrC}$, SiC-fiber-reinforced $\mathrm{ZrC}$, and $\mathrm{Al}_{2} \mathrm{O}_{3}$-reinforced $\mathrm{Al}_{2} \mathrm{O}_{3}$.

Two approaches were taken in assessing the use of the ceramic composites in the proposed power cycles: an equilibrium thermodynamic analysis and a nonequilibrium assessment based on a literature review. In the equilibrium thermodynamic analysis, gas pressures were calculated and the stable liquid and solid phases containing the constituent elements for each ceramic composite-power cycle combination were determined over the appropriate temperature range. For the nonequilibrium assessment, reported results of high-temperature compatibility studies between the ceramic phases and the proposed working fluids were reviewed for indications of detrimental interactions.

\section{EQUILIBRIUM THERMODYNAMIC ANALYSIS}

The equilibrium thermodynamic assessment was performed by calculating the equilibrium state for each set of constituents under the appropriate pressure, temperature, and compositional conditions. The computer program

SOLGASMIX-PV ${ }^{1}$ was used to execute the calculations to determine equilibrium pressures of the gaseous species and the amounts of each of the stable solid and liquid phases. Equilibrium states were computed for sets of conditions for each of the power cycles (Table 1). The species used and

Table 1. Power cycle conditions

\begin{tabular}{llll}
\hline \multirow{2}{*}{ Conditions } & \multicolumn{3}{c}{ Cycles } \\
\cline { 2 - 4 } & Brayton, continuous & Brayton, burst & Rankine \\
\hline Temperature, $\mathrm{K}$ & $\Delta \mathrm{T}, 1100-1500$ & 2500 (once through) & $\Delta \mathrm{T}, 1340-1450$ \\
Pressure, $\mathrm{MPa}$ & Inert gas, 2.76 & Hydrogen, 6.89 & Potassium, 1.38 \\
\hline
\end{tabular}


attendant thermodynamic data are listed in Tables 2 and 3 . Two separate data sets were used for convenience and to avoid exceeding the capacity of the SOLGASMIX-PV program.

Thermodynamic values were obtained from available data compilations, as indicated in Tables 2 and 3 . The values of enthalpy of formation $\left(\Delta \mathrm{H}_{\mathrm{f}}^{\circ}\right.$ ) and entropy $\left(S^{\circ}\right)$ at $1800 \mathrm{~K}$ were used to determine the Gibbs free energy of formation over the entire temperature range of interest. Although this is an approximation, little error is incurred in the free energy values over a range of several hundred degrees. For some species elevated-temperature values were not available, so $298 \mathrm{~K}$ values were used.

For the zirconium silicides, the only values found were $298 \mathrm{~K} \Delta \mathrm{H}_{\mathrm{f}}^{\circ}$. Entropy values at $298 \mathrm{~K}$ for the zirconium silicides thus had to be estimated, and this was done using the averaged $S^{\circ}$ values for other transition metal silicides of the same composition. 6 For phases where data for other metals were not available, $\left(M_{6} S i_{5}\right.$ and $\left.M S i_{1.62}\right)$ values were determined from a curve of $298 \mathrm{~K} \mathrm{~S}^{\circ}$ per gram-atom versus metal/silicon ratio that was constructed from the average values for transition metal silicides that do exist (Fig. 1). Liquid phases were assumed to be adequately modeled with a single, ideal solution.

The results of the thermodynamic calculations are shown as plots of gas and vapor pressures versus temperature for each of the power cycle-ceramic composite systems. Due to the large number of species for which pressures were calculated, each is not shown explicitly on the plots. Rather, the sums of the partial pressures of species having the same elemental constituents are shown. Also indicated on these plots are the stable liquid and solid phases in the equilibrium system at the temperatures shown.

BRAYTON CYCLE, CONTINUOUS MODE

Alumina is thermodynamically stable to $1800 \mathrm{~K}$ based on the pressures indicated in Fig. 2, which show no species pressures in excess of $10^{-5} \mathrm{~Pa}$. 
Table 2. Thermodynamic data at $1800 \mathrm{~K}$ for the $\mathrm{H}-\mathrm{K}-\mathrm{Al}-\mathrm{Si}-\mathrm{C}-\mathrm{O}$ system

\begin{tabular}{|c|c|c|c|c|c|c|c|}
\hline Species & $\begin{array}{c}\Delta \mathrm{H}_{\mathrm{f}}^{o} \\
(\mathrm{~kJ} / \mathrm{mo} 1)\end{array}$ & $\begin{array}{c}S^{0} \\
\left(J-m o 1^{-1}-K^{-1}\right)\end{array}$ & Ref. & Species & $\begin{array}{c}\Delta \mathrm{H}_{\mathrm{f}}^{\circ} \\
(\mathrm{kJ} / \mathrm{mol})\end{array}$ & $\begin{array}{c}S^{0} \\
\left(J-m o 1^{-1}-K^{-1}\right)\end{array}$ & Ref. \\
\hline \multicolumn{4}{|c|}{ Gaseous } & \multicolumn{4}{|c|}{ Gaseous (continued) } \\
\hline $\mathrm{H}_{2}$ & 0.0 & 184.7 & 2 & 0 & 254.9 & 198.9 & 4 \\
\hline $\mathrm{O}_{2}$ & 0.0 & 264.7 & 2 & SiO & -162.8 & 272.7 & 2 \\
\hline Al & 304.7 & 202.1 & 2 & $\mathrm{SiO}_{2}$ & -361.1 & 326.8 & 2 \\
\hline $\mathrm{Al}_{2}$ & 307.9 & 436.3 & 2 & $0_{3}$ & 145.4 & 330.3 & 2 \\
\hline AlH & 234.2 & 247.5 & 2 & $\mathrm{Si}$ & 393.2 & 206.2 & 2 \\
\hline $\mathrm{AlOH}$ & -212.3 & 297.0 & 2 & $\mathrm{SiH}_{4}$ & -25.7 & 335.0 & 3 \\
\hline $\mathrm{A} 1 \mathrm{O}_{2} \mathrm{H}$ & -486.0 & 373.4 & 2 & $\mathrm{Si}_{2}$ & $594.1^{a}$ & $229.8^{a}$ & 6 \\
\hline A10 & 43.1 & 283.1 & 3 & $\mathrm{Si}_{2} \mathrm{H}_{6}$ & $79.9^{a}$ & $274.3^{a}$ & 6 \\
\hline $\mathrm{AlO}_{2}$ & -206.8 & 348.9 & 3 & $\mathrm{Si}_{3}$ & $615.1^{a}$ & $253.7^{a}$ & 6 \\
\hline $\mathrm{Al}_{2} \mathrm{O}$ & -179.2 & 362.4 & 3 & & & & \\
\hline $\mathrm{Al}_{2} \mathrm{O}_{2}$ & -481.0 & 414.1 & 3 & \multirow{2}{*}{\multicolumn{4}{|c|}{ Liquid }} \\
\hline $\mathrm{A} 1 \mathrm{C}$ & 660.1 & 287.9 & 2 & & & & \\
\hline $\mathrm{CH}$ & 590.5 & 240.0 & 2 & $\mathrm{~K}$ & -69.7 & 128.3 & 2 \\
\hline $\mathrm{CH}_{2}$ & 378.0 & 270.2 & 4 & Al & 0.0 & 92.3 & 2 \\
\hline $\mathrm{CH}_{3}$ & 133.7 & 290.0 & 2 & $\mathrm{Si}$ & 0.0 & 93.4 & 2 \\
\hline $\mathrm{CH}_{4}$ & -92.7 & 295.9 & 2 & $\mathrm{Al}_{2} \mathrm{O}_{3}$ & -1601.5 & 290.2 & 3 \\
\hline $\mathrm{CO}^{4}$ & -117.3 & 254.8 & 2 & $\mathrm{~K}_{2} \mathrm{CO}_{3}$ & -1197.8 & 478.1 & 2 \\
\hline $\mathrm{C}$ & 717.4 & 195.4 & 2 & $\mathrm{~K}_{2} \mathrm{SiO}_{3}$ & -1650.5 & 475.9 & 5 \\
\hline $\mathrm{CO}_{2}$ & -397.4 & 302.9 & 2 & $\mathrm{SiO}_{2}$ & -939.5 & 163.8 & 2 \\
\hline $\mathrm{SiC}$ & 661.7 & 288.3 & 2 & & & & \\
\hline $\mathrm{Si}_{2} \mathrm{C}$ & 413.0 & 342.2 & 2 & \multirow{2}{*}{\multicolumn{4}{|c|}{ Crystalline phases }} \\
\hline $\mathrm{C}_{2}$ & 832.5 & 266.6 & 2 & & & & \\
\hline $\mathrm{C}_{2} \mathrm{H}$ & 468.6 & 288.2 & 2 & $\mathrm{Si}$ & -49.9 & 63.7 & 2 \\
\hline $\mathrm{C}_{2} \mathrm{H}_{2}$ & 220.8 & 312.7 & 2 & $\mathrm{C}$ & 0.0 & 38.2 & 2 \\
\hline $\mathrm{C}_{2} \mathrm{H}_{4}$ & 35.3 & 362.4 & 2 & $\alpha-A 1_{2} O_{3}$ & -1683.4 & 256.7 & 5 \\
\hline $\mathrm{C}_{2} \mathrm{H}_{4} \mathrm{O}$ & -66.6 & 416.1 & 2 & B-SiC & -122.9 & 94.2 & 2 \\
\hline $\mathrm{C}_{2} \mathrm{O}$ & 284.4 & 328.9 & 2 & $\mathrm{Al}_{2} \mathrm{SiO}_{5}$ & -2634.5 & 416.1 & 2 \\
\hline $\mathrm{SiC}_{2}$ & 550.0 & 334.7 & 2 & $\mathrm{Al}_{6} \mathrm{O}_{13} \mathrm{Si}$ & -6925.1 & 1116.7 & 2 \\
\hline $\mathrm{C}_{3}$ & 795.6 & 313.3 & 2 & $\mathrm{SiO}_{2}$ & -946.8 & 160.2 & 2 \\
\hline $\mathrm{C}_{3} \mathrm{O}_{2}$ & -93.9 & 436.6 & 2 & $\mathrm{~K}_{2} \mathrm{CO}_{3}$ & -1209.5 & 464.5 & 2 \\
\hline $\mathrm{C}_{4}$ & 960.9 & 353.7 & 2 & $\mathrm{AlH}_{3}$ & $-11.5^{a}$ & $29.3^{a}$ & 6 \\
\hline $\mathrm{H}$ & 226.1 & 152.0 & 2 & $\mathrm{Al}_{4} \mathrm{C}_{3}$ & -265.7 & 380.6 & 2 \\
\hline HO & 37.0 & 238.6 & 2 & $\mathrm{~K}_{2} \mathrm{O}$ & -456.0 & 287.0 & 2 \\
\hline $\mathrm{HO}_{2}$ & -2.1 & 308.3 & 2 & $\mathrm{~K}_{2} \mathrm{O}_{2}$ & -564.1 & 357.2 & 2 \\
\hline $\mathrm{SiH}$ & 315.0 & 256.6 & 2 & $\mathrm{~K}_{2} \mathrm{SiO}_{3}$ & -1693.9 & 440.0 & 5 \\
\hline $\mathrm{H}_{2} \mathrm{~K}_{2} \mathrm{O}_{2}$ & -830.2 & 512.7 & 2 & $\mathrm{Al}_{2} \mathrm{O}_{3} \cdot \mathrm{H}_{2} \mathrm{O}$ & $-2004.2^{a}$ & $28.6^{a}$ & 6 \\
\hline $\mathrm{H}_{2} \mathrm{O}$ & -251.1 & 259.3 & 2 & $\mathrm{Al}_{2} \mathrm{O}_{3} \cdot 3 \mathrm{H}_{2} \mathrm{O}$ & $-2586.6^{8}$ & $140.2^{2}$ & 6 \\
\hline $\mathrm{H}_{2} \mathrm{O}_{2}$ & -141.1 & 324.4 & 2 & $\mathrm{Al}_{4} \mathrm{C}_{3}$ & $-215.7^{a}$ & $88.7^{a}$ & 6 \\
\hline $\mathrm{K}$ & 0.0 & 197.6 & 2 & $\mathrm{~K}_{2} \mathrm{Si}_{2} \mathrm{O}_{5}$ & $-299.2^{a}$ & $182.0^{8}$ & 6 \\
\hline Ko & -17.9 & 305.7 & 2 & $\mathrm{KH}$ & $-57.7^{A}$ & $51.5^{a}$ & 6 \\
\hline $\mathrm{K}_{2}$ & -54.3 & 319.9 & 2 & & & & \\
\hline
\end{tabular}

$a_{\text {Values at }} 298 \mathrm{~K}$. 
Table 3. Thermodynamic data at $1800 \mathrm{~K}$ for the $\mathrm{H}-\mathrm{K}-\mathrm{Zr}-\mathrm{Si}-\mathrm{C}-\mathrm{N}$ system

\begin{tabular}{|c|c|c|c|c|c|c|c|}
\hline Species & $\begin{array}{c}\Delta \mathrm{H}_{\mathrm{f}}^{\circ} \\
(\mathrm{kJ} / \mathrm{mol})\end{array}$ & $\begin{array}{c}\mathrm{S}^{0} \\
\left(\mathrm{~J}-\mathrm{mol}^{-1}-\mathrm{K}^{-1}\right)\end{array}$ & Ref. & Species & $\begin{array}{c}\Delta \mathrm{H}_{\mathbf{f}}^{\circ} \\
(\mathrm{kJ} / \mathrm{mol})\end{array}$ & $\begin{array}{c}S^{0} \\
\left(J-m o 1^{-1}-K^{-1}\right)\end{array}$ & $\operatorname{Ref}$. \\
\hline & Gaseou & & & \multicolumn{4}{|c|}{ Gaseous (continued) } \\
\hline $\mathrm{H}_{2}$ & 0.0 & 184.7 & 2 & $\mathrm{~N}_{3}$ & 423.3 & 320.0 & 5 \\
\hline $\mathrm{K}$ & 0.0 & 197.6 & 2 & Si & 393.2 & 206.2 & 2 \\
\hline $\mathrm{CH}_{2}$ & 378.0 & 270.2 & 4 & $\mathrm{Zr}$ & 1310.1 & 233.5 & 2 \\
\hline CKN & -9.9 & 353.3 & 2 & $\mathrm{CH}$ & 590.5 & 240.0 & 2 \\
\hline $\mathrm{CN}$ & 430.2 & 260.2 & 2 & $\mathrm{CH}_{3}$ & 133.7 & 290.0 & 2 \\
\hline $\mathrm{NCN}$ & 477.4 & 321.9 & 5 & $\mathrm{CH}_{4}$ & -92.7 & 295.9 & 2 \\
\hline C & 717.4 & 195.4 & 2 & $\mathrm{Si}_{2}$ & $594.0^{a}$ & $229.8^{a}$ & 6 \\
\hline $\mathrm{SiC}$ & 661.7 & 288.3 & 2 & $\mathrm{Si}_{2} \mathrm{H}_{6}$ & $79.9^{a}$ & $274.3^{a}$ & 6 \\
\hline $\mathrm{Si}_{2} \mathrm{C}$ & 413.0 & 342.2 & 2 & $\mathrm{Si}_{3}$ & $615 \cdot 0^{a}$ & $253.7^{a}$ & 6 \\
\hline $\mathrm{C}_{2}$ & 832.5 & 266.6 & 2 & & & & \\
\hline $\mathrm{C}_{2} \mathrm{H}$ & 468.4 & 292.4 & 2 & \multirow{2}{*}{\multicolumn{4}{|c|}{ Liquid }} \\
\hline $\mathrm{C}_{2} \mathrm{H}_{2}$ & 220.8 & 312.7 & 2 & & & & \\
\hline $\mathrm{C}_{2} \mathrm{H}_{4}$ & 35.3 & 362.4 & 2 & Si & 0.0 & 93.4 & 2 \\
\hline $\mathrm{C}_{2} \mathrm{~K}_{2} \mathrm{~N}_{2}$ & -174.6 & 588.7 & 2 & $\mathrm{Zr}$ & 18.4 & 101.8 & 2 \\
\hline $\mathrm{C}_{2} \mathrm{~N}$ & 558.0 & 330.9 & 2 & $\mathbf{K}$ & -69.7 & 128.3 & 2 \\
\hline $\mathrm{C}_{2} \mathrm{~N}_{2}$ & 311.6 & 369.2 & 2 & CKN & -166.4 & 269.7 & 2 \\
\hline $\mathrm{SiC}_{2}$ & 550.0 & 334.7 & 2 & & & & \\
\hline$C_{3}$ & 795.6 & 313.3 & 2 & \multicolumn{4}{|c|}{ Crystalline phases } \\
\hline $\mathrm{C}_{4}$ & 961.1 & 353.7 & 2 & & & & \\
\hline $\mathrm{C}_{4} \mathrm{~N}_{2}$ & 538.5 & 489.0 & 2 & $\beta-S i C$ & -122.9 & 94.2 & 2 \\
\hline $\mathrm{C}_{\mathrm{s}}$ & 969.4 & 401.0 & 2 & $\mathrm{ZrC}$ & -199.8 & 123.1 & 2 \\
\hline H & 226.1 & 152.0 & 2 & C & 0.0 & 38.2 & 2 \\
\hline $\mathrm{HN}$ & 377.2 & 236.4 & 5 & $\mathrm{Si}_{3} \mathrm{~N}_{4}$ & -878.5 & 367.6 & 2 \\
\hline HSi & 315.0 & 256.6 & 5 & Si & -49.9 & 63.7 & 2 \\
\hline $\mathrm{HZr}$ & 494.8 & 277.1 & 2 & $\mathrm{Zr}$ & 0.0 & 93.2 & 2 \\
\hline $\mathrm{N}_{2} \mathrm{H}_{2}$ & 208.5 & 316.8 & 2 & CKN & -188.8 & 247.3 & 2 \\
\hline $\mathrm{N}_{2} \mathrm{H}$ & 183.9 & 266.6 & 2 & $\mathrm{KH}$ & $-57.7^{a}$ & $-51.5^{a}$ & 6 \\
\hline $\mathrm{NH}_{3}$ & -55.4 & 283.9 & 2 & $\mathrm{ZrN}$ & $-368.2^{a}$ & $-38.9^{a}$ & 6 \\
\hline $\mathrm{N}_{2} \mathrm{H}_{4}$ & 94.9 & 390.4 & 2 & $\mathrm{ZrH}_{2}$ & $-169.5^{a}$ & $-35.1^{a}$ & 6 \\
\hline $\mathrm{SiH}_{4}$ & -25.7 & 335.0 & 2 & $\mathrm{Zr}_{2} \mathrm{Si}^{2}$ & $-338.9^{b}$ & $-105.4^{b}$ & 2 \\
\hline $\mathrm{K}_{2}$ & -54.3 & 319.9 & 3 & $\mathrm{Zr}_{5} \mathrm{Si}_{3}$ & $-613.8^{b}$ & $-225.9^{b}$ & 2 \\
\hline $\mathrm{N}^{2}$ & 479.4 & 190.6 & 2 & $\mathrm{Zr}_{6} \mathrm{Si}_{5}$ & $-850.6^{b}$ & $-268.8^{b}$ & 2 \\
\hline SiN & 312.9 & 279.3 & 2 & $\mathrm{ZrSi}$ & $-147.7^{b}$ & $-46.9^{b}$ & 2 \\
\hline $\mathrm{Si}_{2} \mathrm{~N}$ & 283.5 & 360.4 & 2 & $\mathrm{ZrSi}_{1.62}$ & $-149.8^{b}$ & $58.4^{b}$ & 2 \\
\hline $\mathrm{N}_{2}$ & 0.0 & 248.2 & 2 & & & & \\
\hline
\end{tabular}

${ }^{a}$ Values are at $298 \mathrm{~K}$.

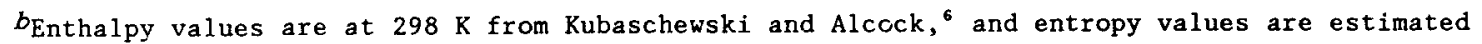
for $298 \mathrm{~K}$ as described in the text. 


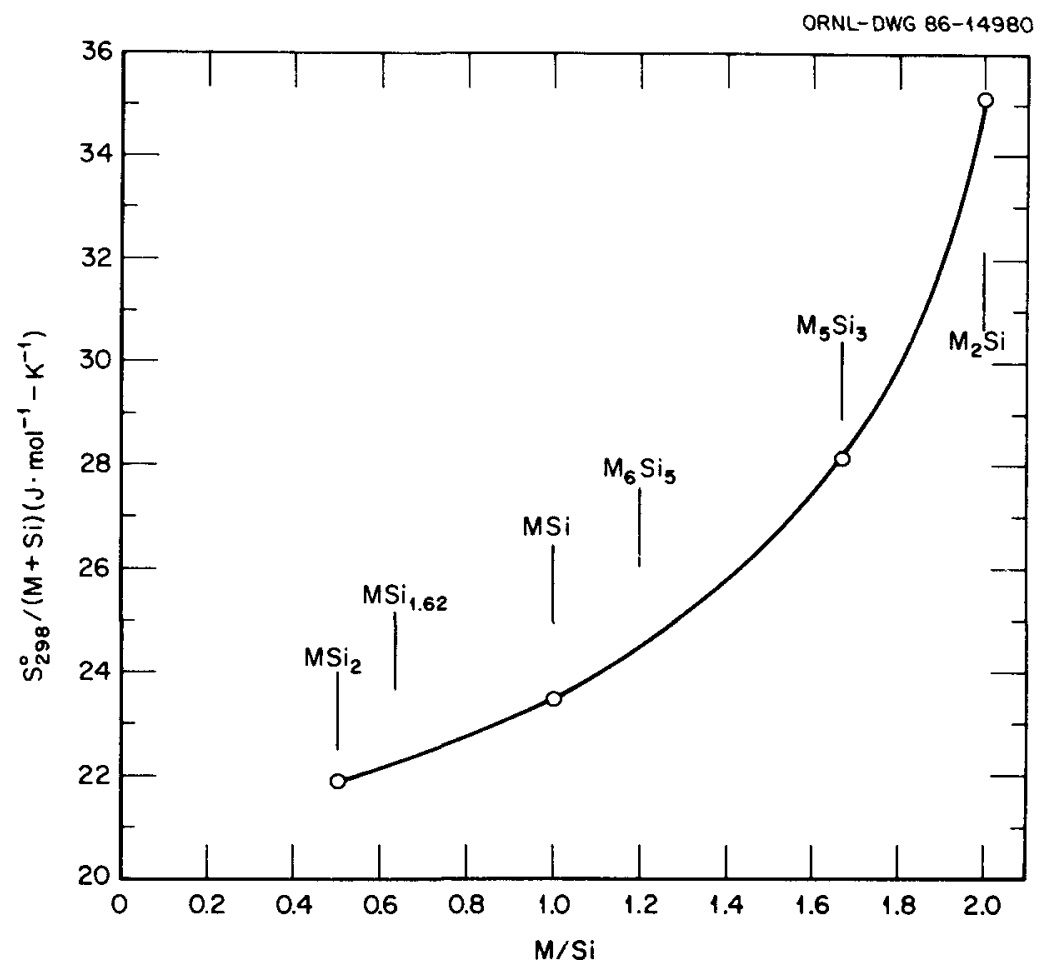

Fig. 1. Entropy per gram-atom at $298 \mathrm{~K}$ of transition metal (M) silicides versus $\mathrm{M} / \mathrm{Si}$ ratio. Source of entropy data: 0 . Kubaschewski and C. B. Alcock, Metallurgical Thermochemistry, 5th ed., Pergamon Press, Ltd., Oxford, U.K., 1979, pp. 268-323.

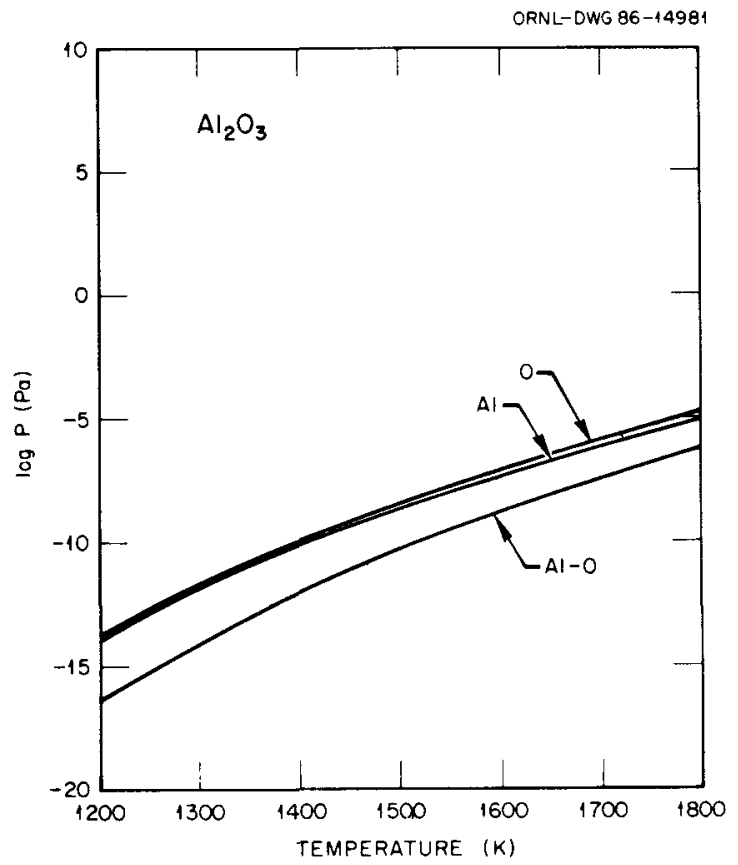

Fig. 2. Equilibrium partial pressures over $\mathrm{Al}_{2} \mathrm{O}_{3}$ in $2.76 \mathrm{MPa}$ of inert gas. 
SiC-whisker-toughened $\mathrm{Al}_{2} \mathrm{O}_{3}$, however, is significantly less stable, with $\mathrm{C}-0, \mathrm{Si}-0$, and aluminum species exhibiting pressures well above $100 \mathrm{~Pa}$ at $1800 \mathrm{~K}$ (Fig. 3).

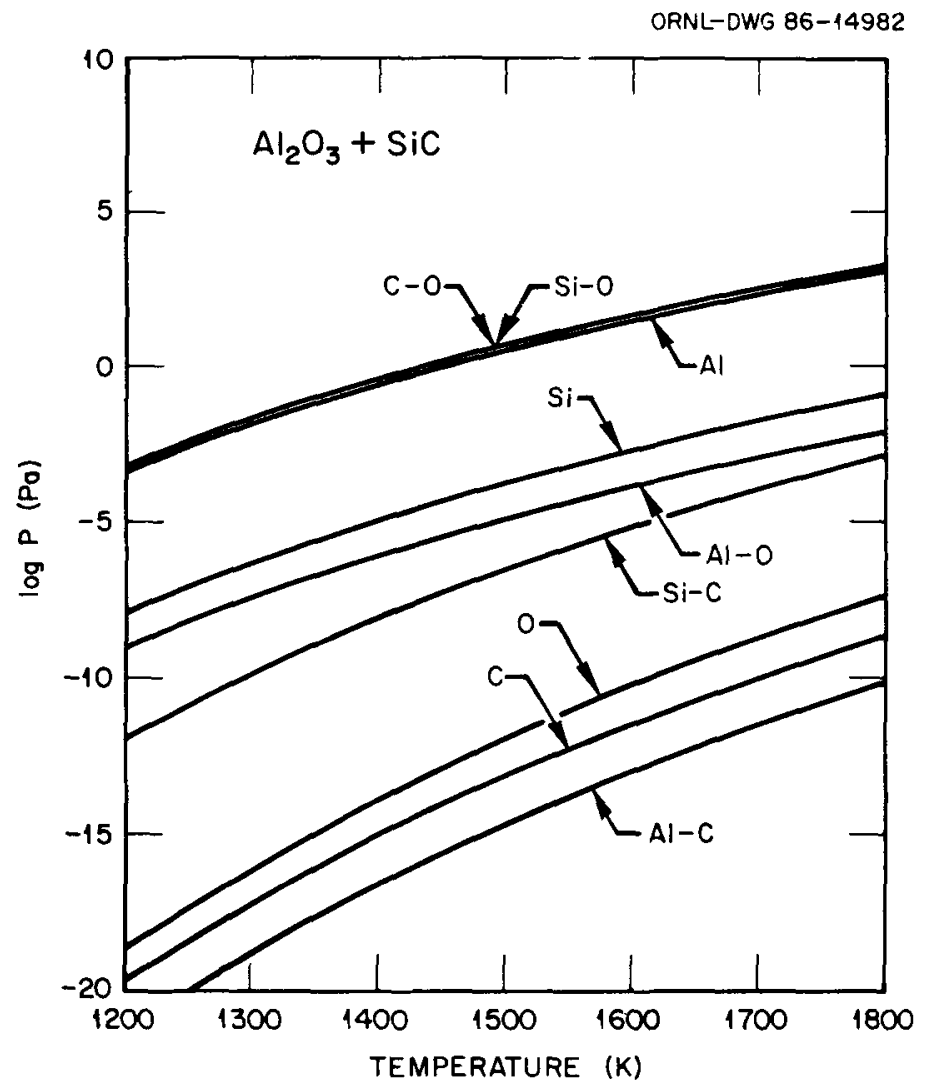

Fig. 3. Equilibrium partial pressures over $\mathrm{Al}_{2} \mathrm{O}_{3}$ and $\mathrm{SiC}$ in $2.76 \mathrm{MPa}$ of inert gas.

Carbon-fiber-reinforced $\mathrm{ZrC}$ has extremely low vapor pressures to $1800 \mathrm{~K}$ with only carbon species exhibiting any significant pressure $\left(<10^{-7} \mathrm{~Pa}\right)$, as shown in Fig. 4. Silicon carbide-fiber-reinforced $\mathrm{ZrC}$, however, is calculated to have moderate silicon species pressures equalling $10^{-2} \mathrm{~Pa}$ at $1800 \mathrm{~K}$ (Fig. 5).

Silicon carbide-whisker-toughened $\mathrm{Si}_{3} \mathrm{~N}_{4}$ suffers from high nitrogen species pressures over the temperature range, with a value of almost $1 \mathrm{kPa}$ at $1800 \mathrm{~K}$ (Fig. 6). Silicon-containing species also have substantial pressures in this system. 


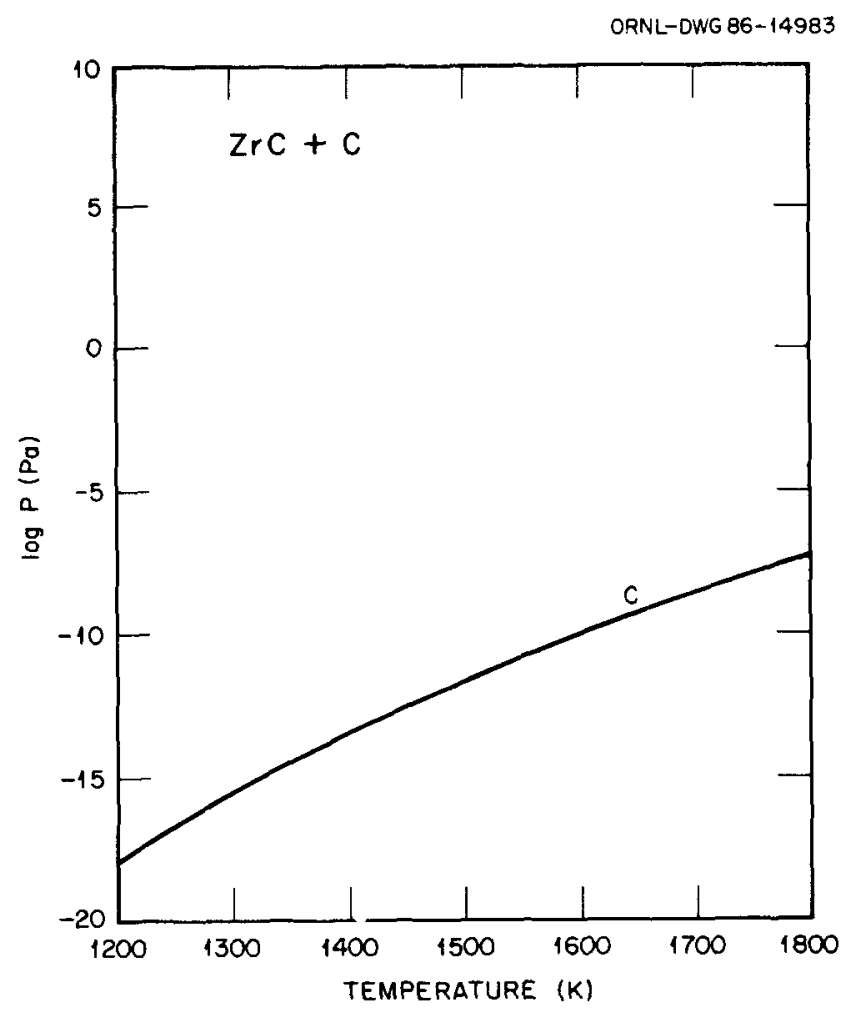

Fig. 4. Equilibrium partial pressures over $\mathrm{ZrC}$ and $\mathrm{C}$ in $2.76 \mathrm{MPa}$ of inert gas.

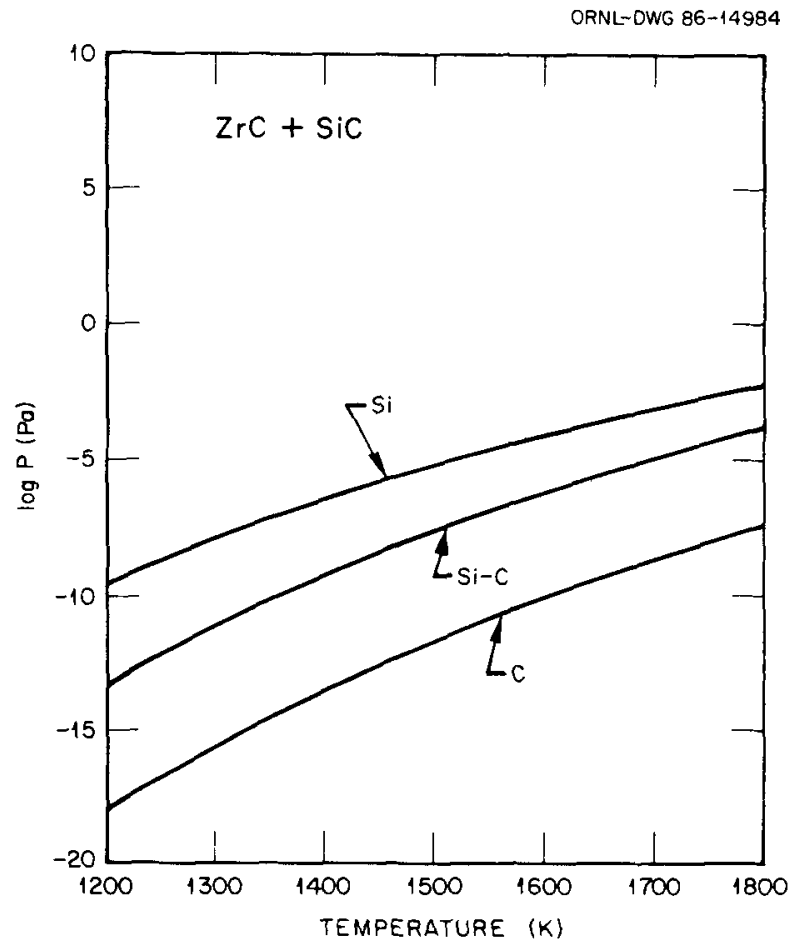

Fig. 5. Equilibrium partial pressures over $\mathrm{ZrC}$ and $\mathrm{SiC}$ in $2.76 \mathrm{MPa}$ of inert gas. 


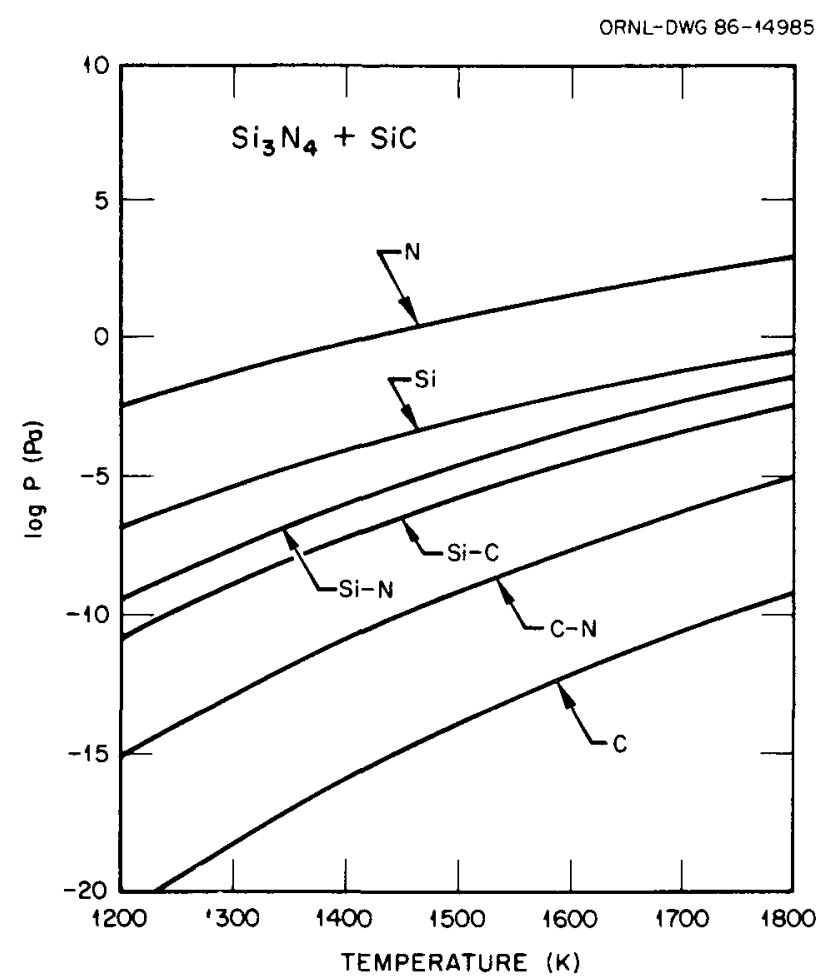

Fig. 6. Equilibrium partial pressures over $\mathrm{Si}_{3} \mathrm{~N}_{4}$ and $\mathrm{SiC}$ in $2.76 \mathrm{MPa}$ of inert gas.

BRAYTON CYCLE, BURST MODE

The alumina-based composites are unstable in hydrogen at the high operating temperatures, forming a liquid phase and generating $\mathrm{H}-\mathrm{O}$ and aluminum species pressures near $100 \mathrm{kPa}$ at $2500 \mathrm{~K}$ (Fig. 7). Silicon carbide-whisker-toughened $\mathrm{Al}_{2} \mathrm{O}_{3}$ also exhibits undesirable equilibrium properties with species pressures in excess of $1 \mathrm{MPa}$ and the formation of a liquid phase above $1500 \mathrm{~K}$ (Fig. 8).

Carbon-fiber-reinforced $\mathrm{ZrC}$ reacts with hydrogen to generate high pressures of hydrocarbons, of the order of $1 \mathrm{MPa}$, over the entire temperature range of the calculations $(1300-2500 \mathrm{~K})$. Less than $1 \mathrm{~Pa}$ of other species such as carbon and $\mathrm{Zr}-\mathrm{H}$ are also generated (Fig. 9). 


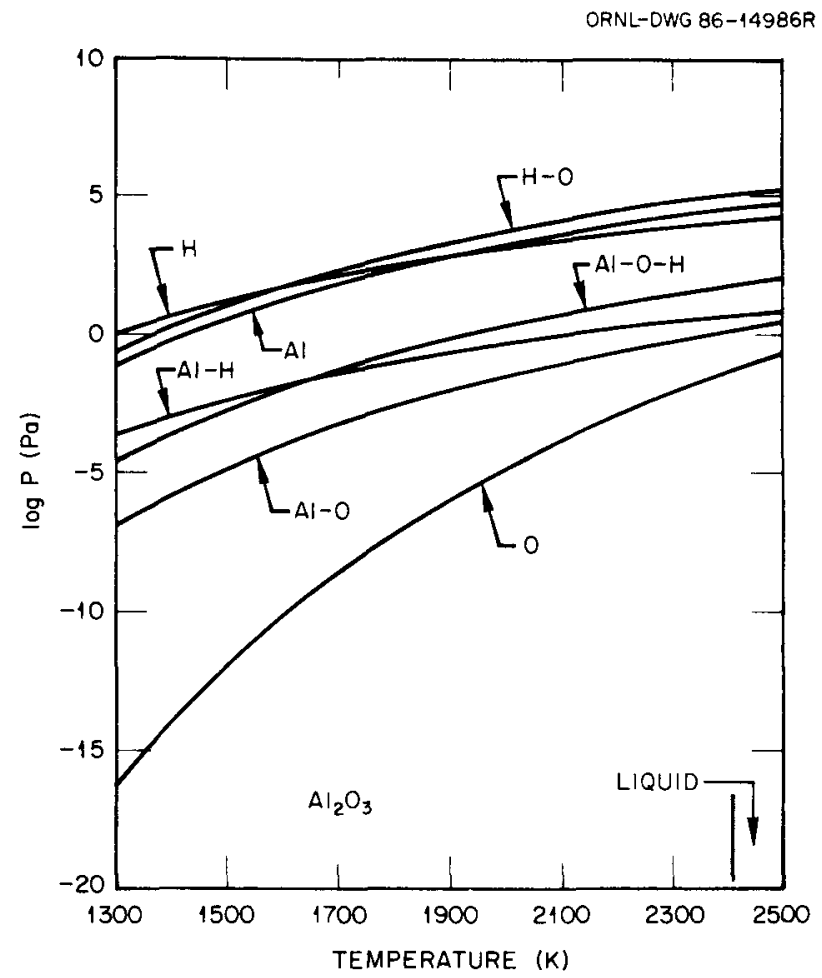

Fig. 7. Equilibrium partial pressures over $\mathrm{Al}_{2} \mathrm{O}_{3}$ in $6.89 \mathrm{MPa}$ of hydrogen.

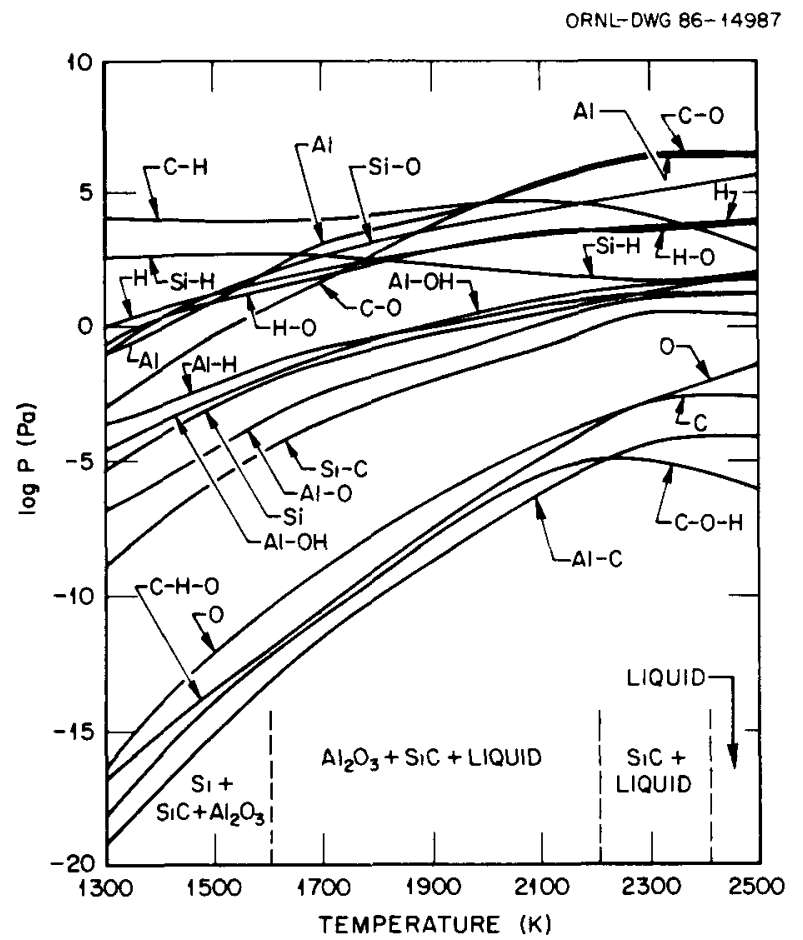

Fig. 8. Equilibrium partial pressures over $\mathrm{Al}_{2} \mathrm{O}_{3}$ and $\mathrm{SiC}$ in $6.89 \mathrm{MPa}$ of hydrogen. The liquid phase is $\mathrm{Al}$ and $\mathrm{Si}$ containing dissolved $\mathrm{Al}_{2} \mathrm{O}_{3}$ and SiC. 


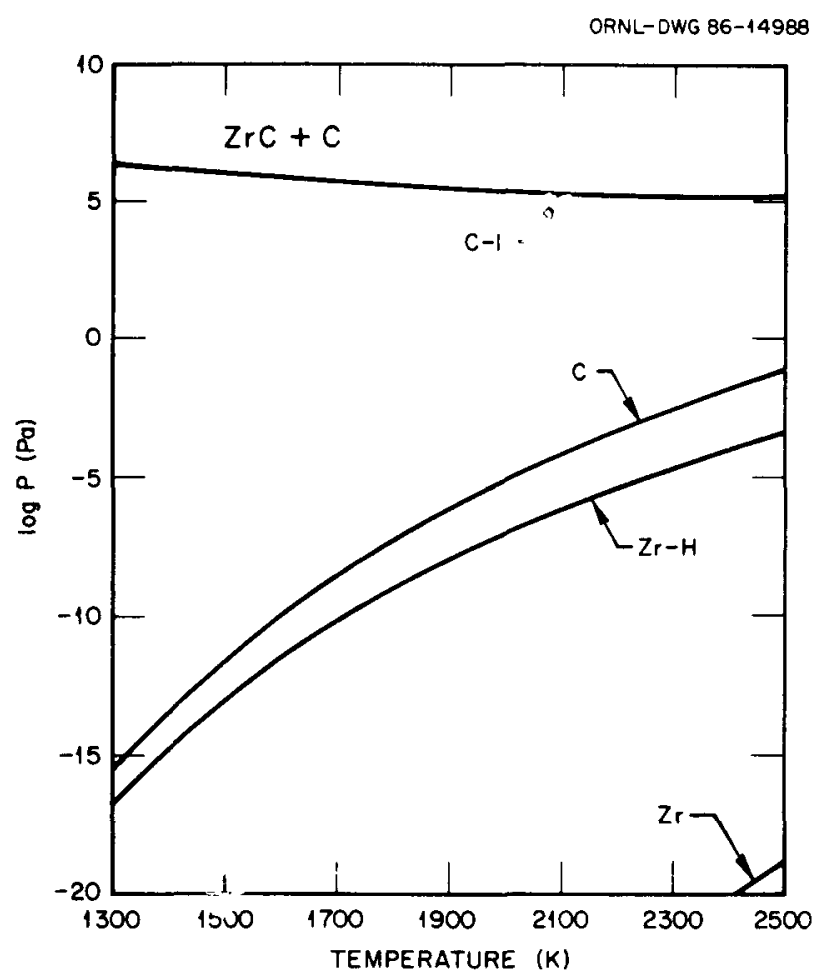

Fig. 9. Equilibrium partial pressures over $\mathrm{ZrC}$ and $\mathrm{C}$ in $6.89 \mathrm{MPa}=\bar{\xi}$ hydrogen.

Silicon carbon-fiber-reinforced $\mathrm{ZrC}$ not only also exhibited substantial hydrocarbon pressures under these conditions, but indicated the formation of a liquid phase above $1500 \mathrm{~K}$ as well (Fig. 10).

The $\mathrm{SiC}$-whisker-toughened $\mathrm{Si}_{3} \mathrm{~N}_{4}$ material generates significant nitrogen pressures at these high temperatures, more than $1 \mathrm{MPa}$ at $2500 \mathrm{~K}$. In addition, a number of species such as the hydrocarbons, $\mathrm{H}-\mathrm{N}$, and $\mathrm{Si}-\mathrm{H}$ also maintain significant pressures down to lower temperatures $(1300 \mathrm{~K})$ (Fig. 11).

\section{RANKINE CYCLE}

The alumina ceramic composite is calculated to be relatively stable in the presence of potassium with $\mathrm{K}-0$ species pressures less than $10^{-3} \mathrm{~Pa}$ at $1550 \mathrm{~K}$ (Fig. 12). Silicon carbide-whisker-toughened $\mathrm{Al}_{2} \mathrm{O}_{3}$, however, has significant aluminum, $\mathrm{C}-\mathrm{O}$, and $\mathrm{Si}-0$ pressures under these conditions (Fig. 13). 


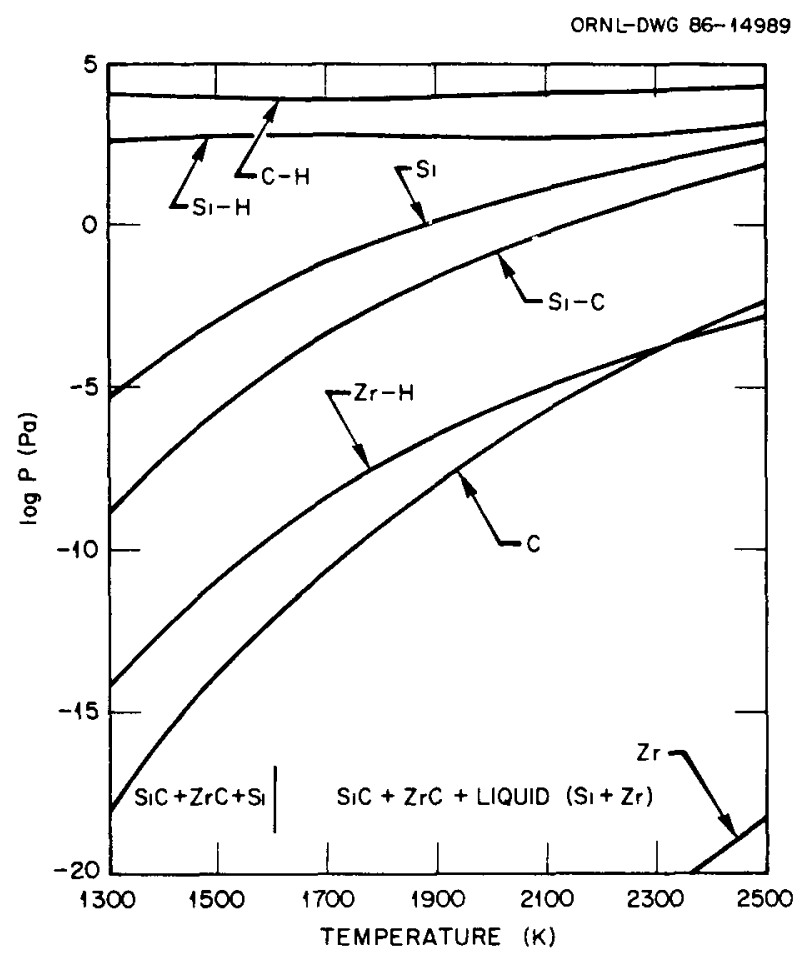

Fig. 10. Equilibrium partial pressures over $\mathrm{ZrC}$ and $\mathrm{SiC}$ in $6.89 \mathrm{MPa}$ of hydrogen.

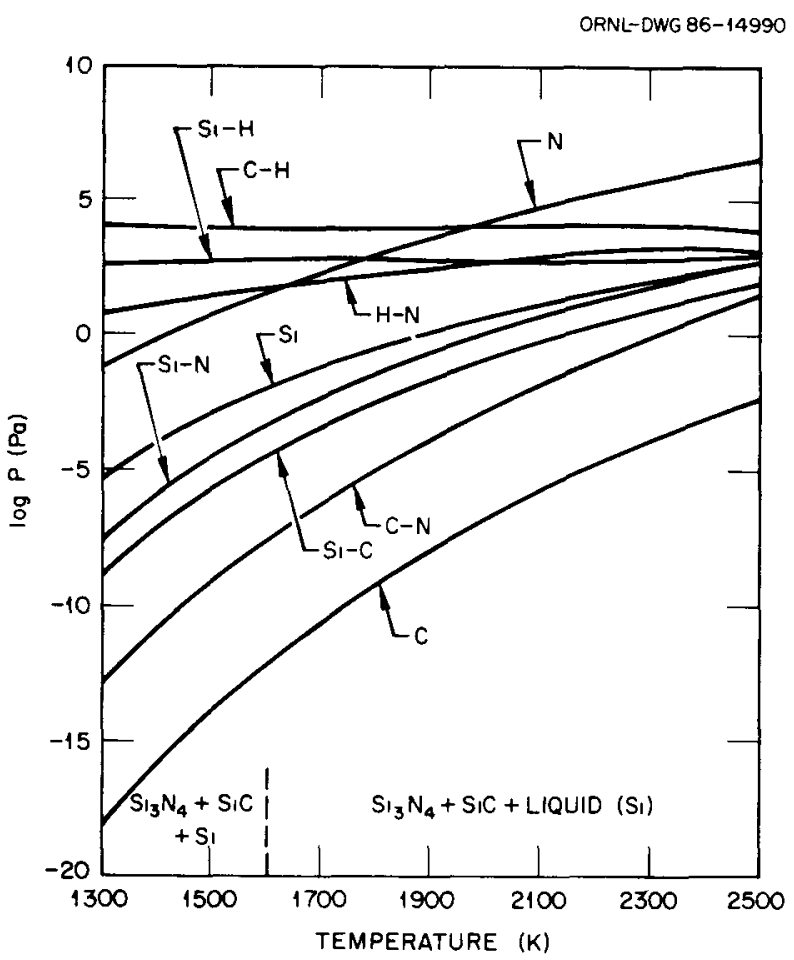

Fig. 11. Equilibrium partial pressures over $\mathrm{Si}_{3} \mathrm{~N}_{4}$ and $\mathrm{SiC}$ in $6.89 \mathrm{MPa}$ of hydrogen. 


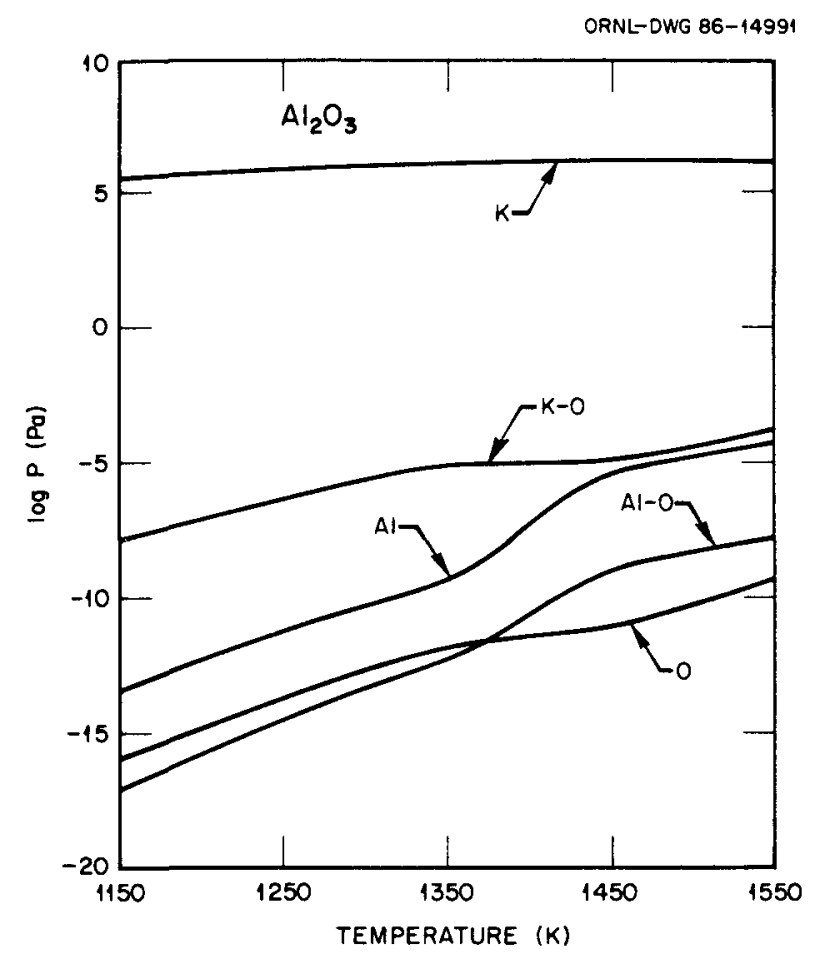

Fig. 12. Equilibrium partial pressures over $\mathrm{Al}_{2} \mathrm{O}_{3}$ in $1.38 \mathrm{MPa}$ of potassium vapor and liquid.

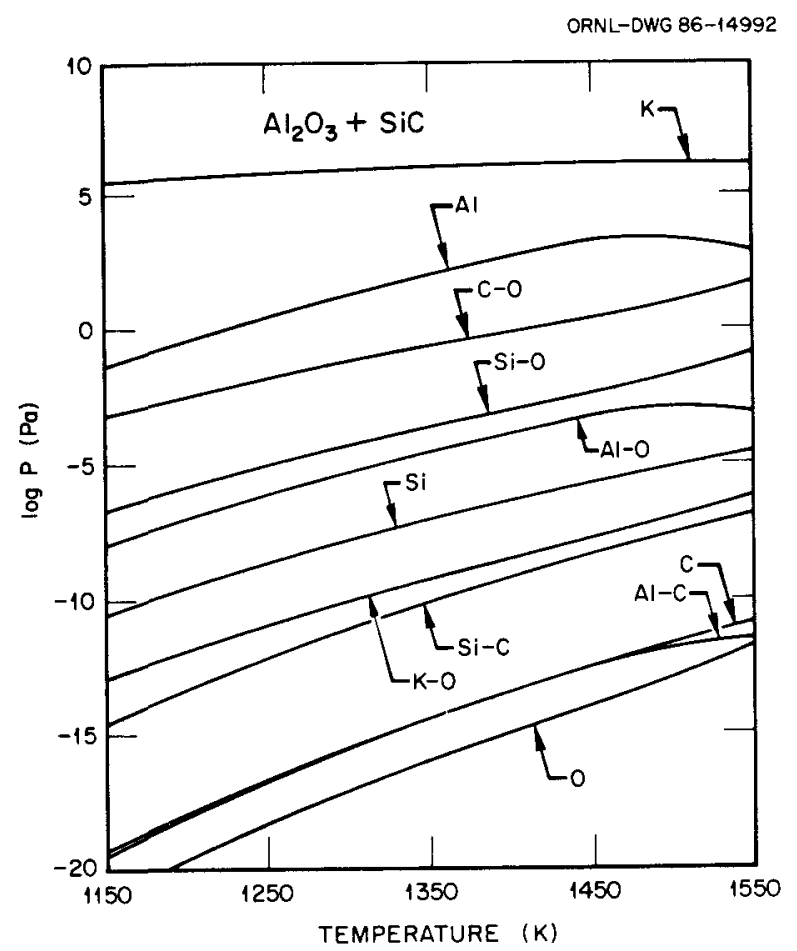

Fig. 13. Equilibrium partial pressures over $\mathrm{Al}_{2} \mathrm{O}_{3}$ and $\mathrm{SiC}$ in $1.38 \mathrm{MPa}$ of potassium vapor and liquid. 
Carbon-fiber-reinforced $\mathrm{ZrC}$ is thermodynamically stable in potassium under these conditions with only a minor carbon species pressure calculated (Fig. 14). Silicon carbide-fiber-reinforced $\mathrm{ZrC}$ also appears to be relatively stable, with the largest species pressure being that of silicon at less than $10^{-4} \mathrm{~Pa}$ at $1550 \mathrm{~K}$ (Fig. 15).

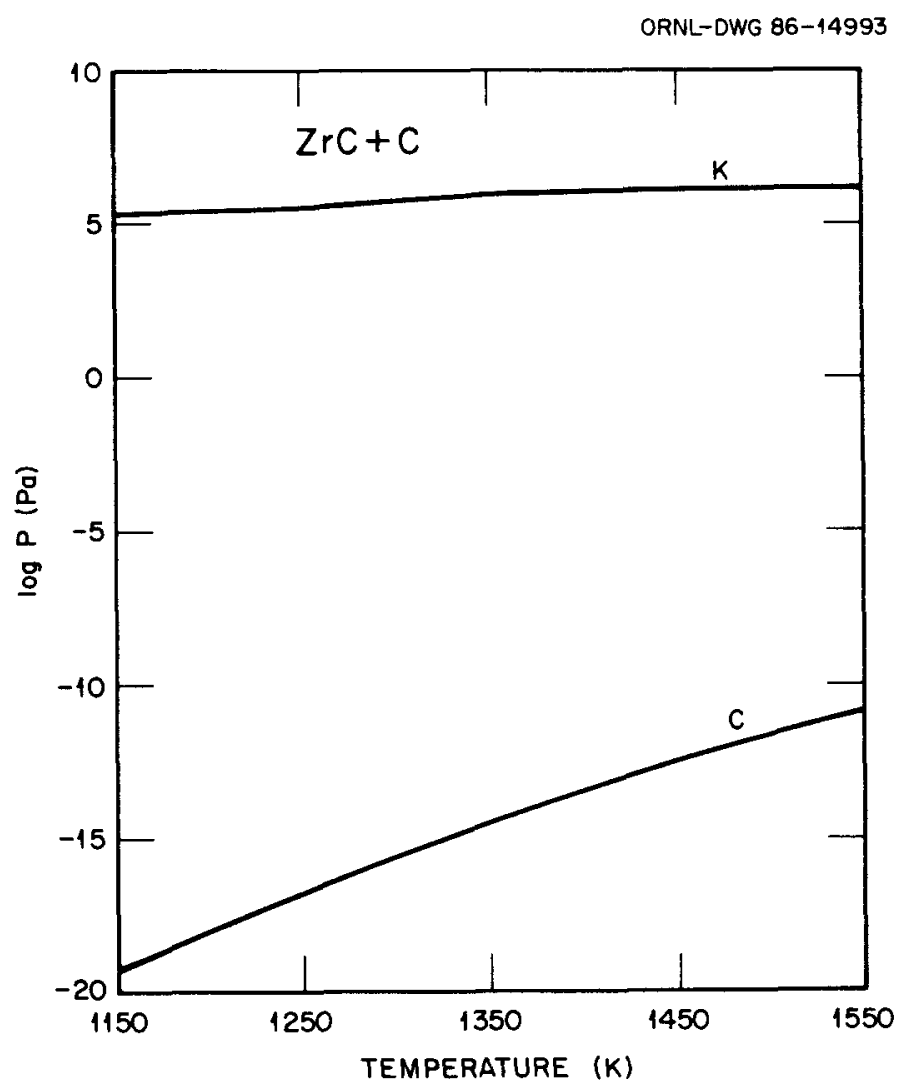

Fig. 14. Equilibrium partial pressures over $\mathrm{ZrC}$ and $\mathrm{C}$ in $1.38 \mathrm{MPa}$ of potassium vapor and liquid.

The SiC-whisker-toughened $\mathrm{Si}_{3} \mathrm{~N}_{4}$ shows less stability than do the other systems, with nitrogen having an equilibrium pressure greater than $10 \mathrm{~Pa}$ (Fig. 16).

\section{NONEQUILIBRIUM ASSESSMENT}

The nonequilibrium assessment of the candidate ceramic composites is based on a review of the literature with regard to observed interactions between the composite components and the environment of the proposed power 


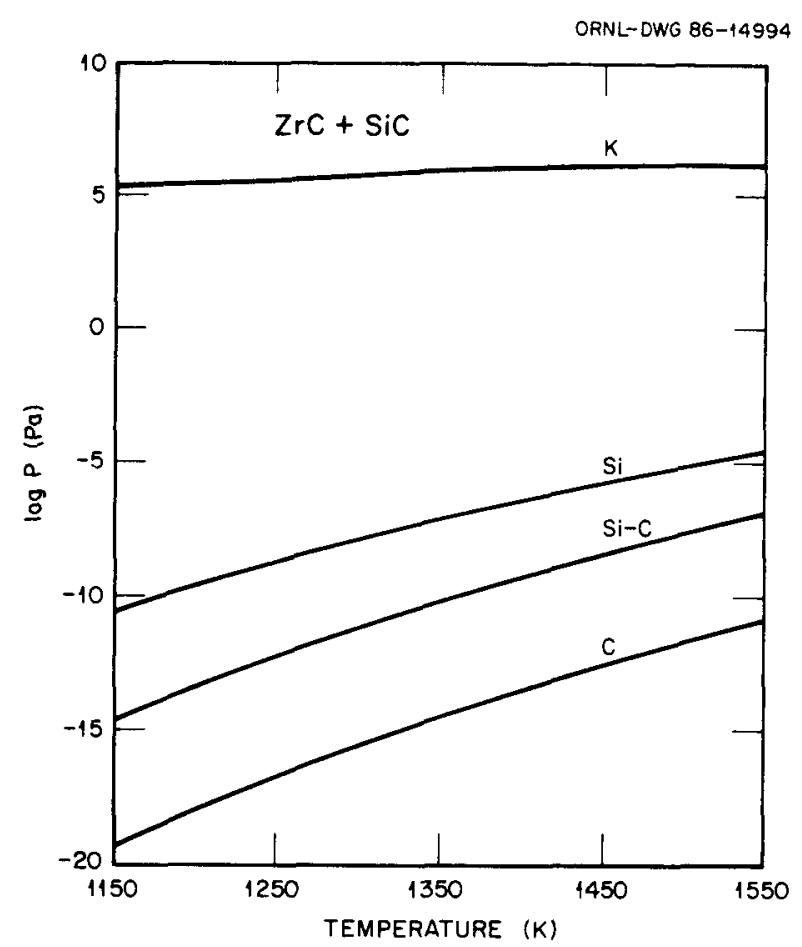

Fig. 15. Equilibrium partial pressures over $\mathrm{ZrC}$ and $\mathrm{SiC}$ in $1.38 \mathrm{MPa}$ of potassium vapor and liquid.

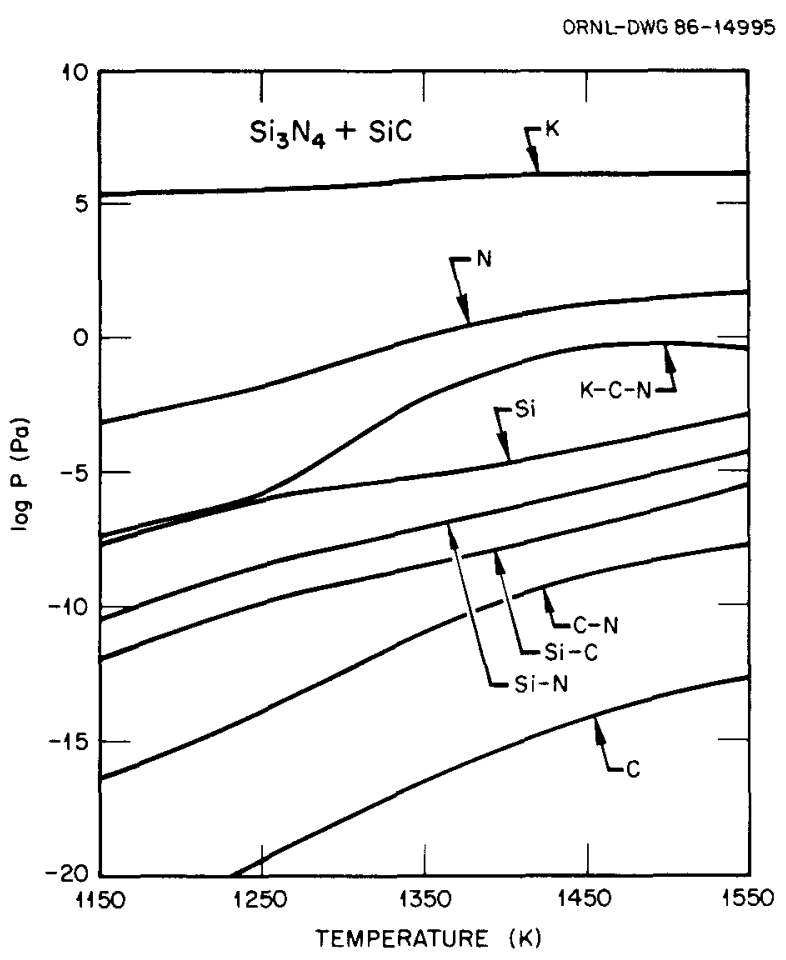

Fig. 16. Equilibrium partial pressures over $\mathrm{Si}_{3} \mathrm{~N}_{4}$ and $\mathrm{SiC}$ in $1.38 \mathrm{MPa}$ of potassium vapor and liquid. 
cycles. Unfortunately, there have been few studies of these interactions, and those that have been reported are typically for temperatures well below those of the system designs. McKee and Chatterji ${ }^{7}$ studied the corrosion of $\mathrm{SiC}$ in $\mathrm{N}_{2}$ and $\mathrm{H}_{2}$ at $1173 \mathrm{~K}$ and found no material loss or reaction. Horn et $a 1 .^{8}$ observed significant erosion of SiC beginning at $1400 \mathrm{~K}$ in steam-hydrogen mixtures, but they attributed the reaction to the effect of the steam. Alumina was also evaluated in steam-hydrogen, but it displayed little erosion to $1550 \mathrm{~K}$, the maximum temperature used in the study. Sheehan ${ }^{9}$ examined the effect of helium containing $\mathrm{H}_{2}, \mathrm{H}_{2} \mathrm{O}, \mathrm{CO}$, and $\mathrm{CH}_{4}$ impurities on alumina and $\mathrm{Si}_{3} \mathrm{~N}_{4}$ to $1200 \mathrm{~K}$ and found the alumina to be unaffected and the $\mathrm{Si}_{3} \mathrm{~N}_{4}$ to undergo passive oxidation. Strength tests following 5000-h exposures showed no strength degradation.

Cook $^{10}$ did a scoping study of the corrosion resistance of various ceramics and cermets to liquid metals. Although potassium was not included as a corrodent, sodium was, and it is expected that the response of the ceramics to the two alkali metals will be similar. It was found that $\mathrm{ZrC}$ exposed to sodium for $100 \mathrm{~h}$ at $1089 \mathrm{~K}$ showed zero depth of attack, zero percentage weight change, and zero dimensional change. Alumina, SiC, and $\mathrm{Si}_{3} \mathrm{~N}_{4}$ were described as having fair to good resistance to corrosion, which was defined as less than 25- $\mu$ m depth of attack, less than $2 \%$ weight change, and less than $1 \%$ dimensional change. Blanc et al. ${ }^{11}$ studied the inclusion of potassium in alumina at $2073 \mathrm{~K}$ and determined that there was little solubility for the alkali metal (5-10 ppm) and therefore little effect of exposure to potassium.

\section{CONCLUSIONS AND RECOMMENDATIONS}

The compatibility of the ceramic composites determined from the equilibrium calculations may be conservative since equilibrium may never be reached because of mass transport or chemical kinetic constraints. The conclusions of the equilibrium assessment, based on calculated partial pressures, are summarized in Fig. 17. To illustrate the effect of significant species pressures on mass transport in a system, consider the 
example of the calculated $10^{-3} \mathrm{~Pa}$ partial pressure of silicon over SiCwhisker-toughened $\mathrm{Si}_{3} \mathrm{~N}_{4}$ in inert gas at $1500 \mathrm{~K}$. Assuming the current design criteria of $241 \mathrm{~kg} / \mathrm{s}$ gas flow $(72 \% \mathrm{He}, 28 \% \mathrm{Xe}$ ) at $2.76 \mathrm{MPa}$, and equilibrium partial pressures maintained in the hot $(1500 \mathrm{~K})$ and cold $(1100 \mathrm{~K})$ regions of the system, $16.7 \mathrm{~kg} /$ year of silicon will be vaporized from the hotter region and condensed in the lower-temperature regions. It is likely that this rate of mass transport would be unacceptable.

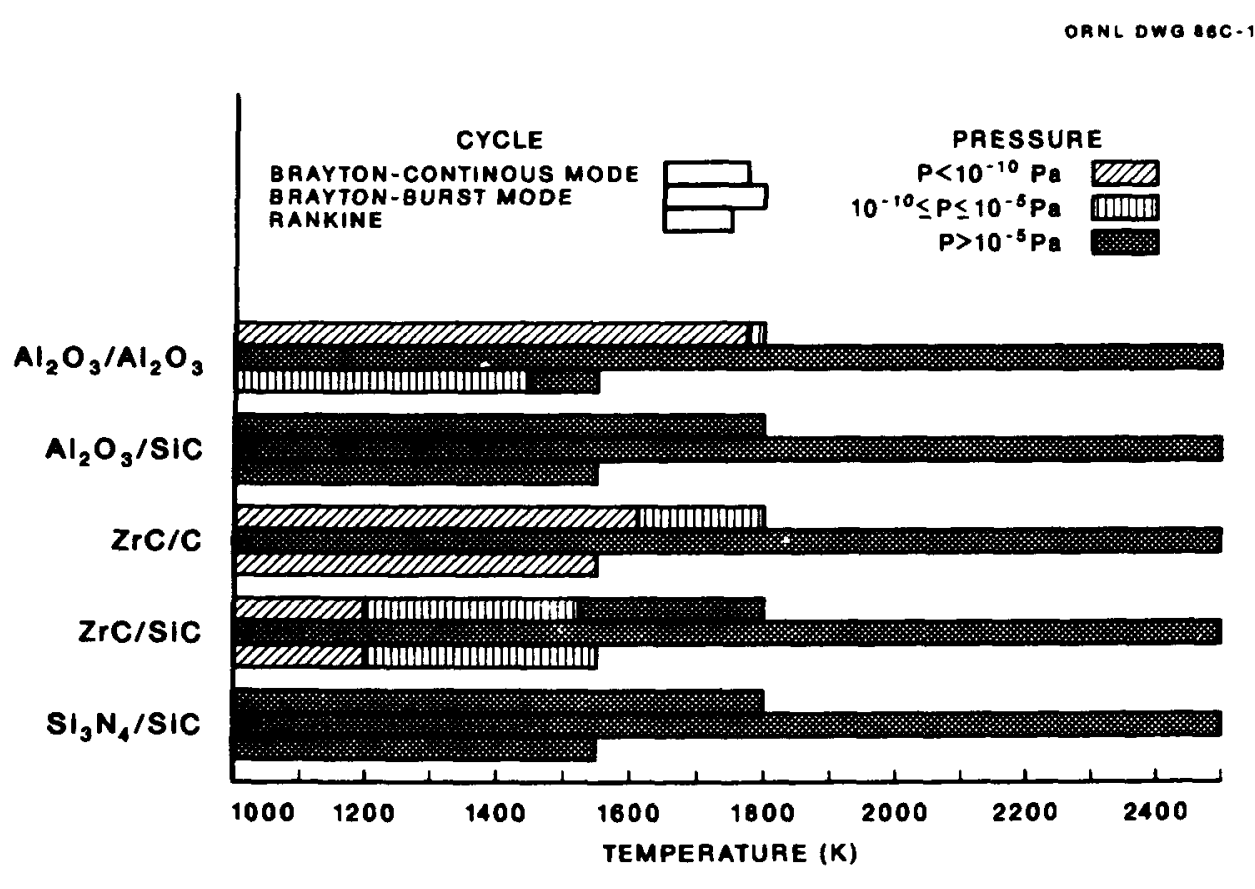

Fig. 17. Summary of the conclusions of the thermodynamic equilibrium assessment. The stabilities of the ceramic-ceramic composites are related to the maximum species pressures, which are shown in the figure. Equilibrium pressures less than $10^{-10} \mathrm{~Pa}$ indicate that the system is stable; pressures between $10^{-10}$ and $10^{-5} \mathrm{~Pa}$ indicate less, but possibly acceptable, stability; and pressures greater than $10^{-5} \mathrm{~Pa}$ indicate unstable systems.

Using the criteria for the Brayton-cycle continuous-mode power system, the composites containing $\mathrm{Al}_{2} \mathrm{O}_{3}, \mathrm{ZrC}$, or carbon appear to be thermodynamically stable. The SiC-containing systems, however, are likely to have unacceptably high silicon partial pressures. 
The combination of hydrogen and the extreme temperature of the Braytoncycle burst-mode system eliminates all of the ceramic composites considered. Should the system need to operate for a very short period of time it may be possible to tolerate material vaporization, although such material loss would have to be accommodated in the design. Experimental observations at lower temperatures (1173-1550 K) of interactions with hydrogen, however, indicate little degradation of alumina and $\mathrm{Si}_{3} \mathrm{~N}_{4}$ and little likely degradation of SiC.

For the Rankine-cycle systems the $\mathrm{Al}_{2} \mathrm{O}_{3}$ composite, SiC-fiberreinforced $\mathrm{ZrC}$, and carbon-fiber-reinforced $\mathrm{ZrC}$ appear to have acceptable thermodynamic equilibrium stabilities. These systems also appear to have fair to good compatibility based on experimental determinations.

Based on the above considerations, it is recommended that $\mathrm{Al}_{2} \mathrm{O}_{3}$ reinforced $\mathrm{Al}_{2} \mathrm{O}_{3}$ and carbon-fiber-reinforced $\mathrm{ZrC}$ be considered for the Brayton-cycle continuous-mode system and that $\mathrm{Al}_{2} \mathrm{O}_{3}$-reinforced $\mathrm{Al}_{2} \mathrm{O}_{3}$, SiCfiber-reinforced $\mathrm{ZrC}$, and carbon-fiber-reinforced $\mathrm{ZrC}$ be considered for the Rankine-cycle system. None of the candidate ceramic composite systems are likely to be sufficiently stable under Braytor-cycle burst-mode conditions.

\section{REFERENCES}

1. T. M. Besmann, SOLGASMIX-PV, a Computer Program to Calculate Equilibrium Relationships in Complex Chemical Systems, ORNL/TM-5775, April 1977.

2. D. R. Stul1 and H. Prophet, project directors, JANAF Thermochemical Tables, $2 \mathrm{~d}$ ed., NSRDS-NBS 37, U.S. Government Printing Office, June 1971 .

3. M. W. Chase, J. L. Curnutt, R. A. McDonald, and A. N. Syverud, "JANAF Thermochemical Tables 1978 Supplement," J. Phys. Ref. Data 7(3), 793-940 (1978).

4. M. W. Chase, J. L. Curnutt, H. Prophet, R. A. McDonald, and A. N. Syverud, "JANAF Thermochemical Tables 1975 Supplement," J. Phys. Ref. Data 4(1), 1-175 (1975). 
5. M. W. Chase, J. L. Curnutt, A. T. Hu, and H. Prophet, "JANAF Thermochemical Tables, 1974 Supplement," J. Phys. Chem. Ref. Data 3(2), 311-480 (1974).

6. 0. Kubaschewski and C. B. Alcock, Metallurgical Thermochemistry, 5th ed., Pergamon Press, Ltd., Oxford, U.K., 1979, pp. 268-323.

7. D. W. McKee and D. Chatterji, "Corrosion of Silicon Carbide in Gases and Alkaline Melts," J. Am. Ceram. Soc. 59(9-10), 441-44 (1976).

8. F. L. Horn, J. A. Fillo, and J. R. Powe11, "Performance of Ceramic Materials in High Temperature Steam and Hydrogen, " J. Nuc1. Mater. 85\&86, 439-43 (1979).

9. J. E. Sheehan, Elevated Temperature Controlled-Impurity Helium Aging of Ceramics, GA-A15411, General Atomic Company, San Diego, July 1979.

10. W. H. Cook, Corrosion Resistance of Various Ceramics and Cermets to Liquid Metals, ORNL-2391, May 1960.

11. M. Blanc, A. Mocellin, and J. L. Strude1, "Observation of Potassium B'"'Alumina in Sintered Alumina," J. Am. Ceram. Soc. 60(9-10), 403-09 (1977). 
page blank 
INTERNAL DISTRIBUTION

ORNL/TM-10267

Dist. Category UC -25

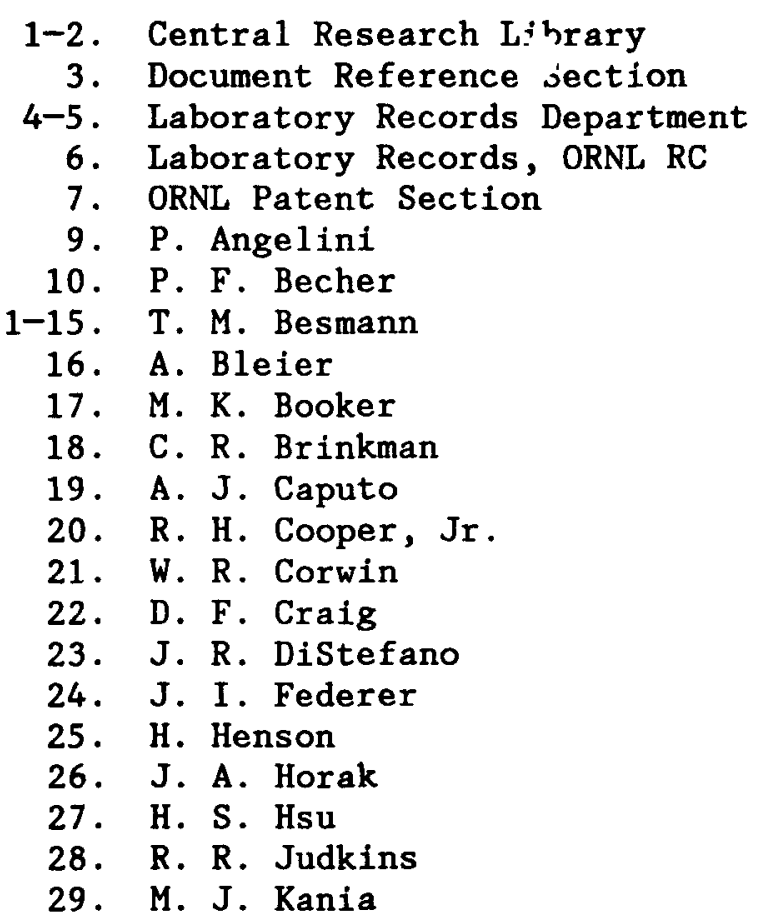

30. J. R. Keiser

31. J. F. King

32. M. M. Martin

33. H. E. McCoy

34. D. L. McElroy

35. R. E. Pawe 1

36. D. F. Pedraza

37. J. M. Robbins

38. A. C. Schaffhauser

39. G. M. Slaughter

40. J. 0. Stiegler

41. D. P. Stinton

42. R. A. Strehlow

43-45. P. T. Thornton

46. F. W. Wiffen

47. R. J. Charles (Consultant)

48. G. Y. Chin (Consultant)

49. H. E. Cook (Consultant)

50. Alan Lawley (Consultant)

51. W. D. Nix (Consultant)

52. J. C. Williams (Consultant)

EXTERNAL DISTRIBUTION

53. ARGONNE NATIONAL LABORATORY, 9700 South Cass Avenue, Argonne, IL 60439

S. K. Bhattacharyya

54-57. BATTELLE PACIFIC NORTHWEST LABORATORIES, P.0. Box 999, Richland, WA 99352
J. 0. Barner
W. J. Krotiuk
B. M. Johnson
R. D. Widrig

58. BROOKHAVEN NATIONAL LABORATORY, Upton, NY 11973

J. R. Powe11

59. HANFORD ENGINEERING DEVELOPMENT LABORATORY, P.0. BOX 1970, Richland, WA, 99352

D. S. Dutt

60-63. IDAHO NATIONAL ENGINEERING LABORATORY, P.0. Box 1625, Idaho Fa11s, ID 83415
J. A. Dearien
J. W. Martine11
J. W. Henscheid
R. E. Rice 
64. JET PROPULSION LABORATORY, Deputy Project Manager for Aerospace Technology, SP-100 Project Office, MS 506-432, 4800 Oak Grove Drive, Pasadena, CA 91109

J. F. Mondt

65-68. LOS ALAMOS NATIONAL LABORATORY, P.0. Box 1633, Los Alamos, NM 87545
C. R. Be11
S. V. Jackson
R. J. Boh1
M. A. Merrigan

69. LAWRENCE LIVERMORE NATIONAL LABORATORY, L-275, BOX 808. Livermore, CA 94550

C. E. Walter

70. NASA LEWIS RESEARCH CENTER, 2100 Brookpart Road, Cleveland, OH 44135

R. J. Sovie

71-72. SANDIA NATIONAL LABORATORIES, Department Manager, Division 6430, P.0. Box 5800, Albuquerque, NM 87185
N. R. Ortiz
F. V. Thome

73. WESTINGHOUSE ELECTRIC CORPORATION, Manager, Materials Technology Advanced Energy Systems Division, P.0. Box 10864, Pittsburgh, PA 15236

R. W. Buckman

74. W. J. SCHAFER ASSOCIATION, 1901 N. Fort Myer Drive, Suite 800, Arlington, VA 22209

S. A. Bassett

75-76. SDIO/SL, THE PENTAGON, Washington, DC 20301-7100
R. L. Verga
R. L. Wiley

77. U.S. DEPARTMENT OF ENERGY, Dep/NE521, Washington, DC 20545

D. R. Bennett

78-79. U.S. DEPARTMENT OF ENERGY, Office of Space Reactor Projects, NE-54 Washington, DC 20545
W. P. Carroll
E. U. Khan

80. U.S. DEPARTMENT OF ENERGY, DP-22.2 Germantown, Washington, DC 20545 R. D. Hahn 
81. U.S. DEPARTMENT OF ENERGY, Division of Defense Energy Projects, Washington, DC 20545

E. J. Wahlquist

82. U.S. DEPARTMENT OF ENERGY, P.O. Box 550, Richland, WA 99353

K. R. Absher

83. U.S. DEPARTMENT OF ENERGY, 785 DOE Place, Shelly, ID 83275

P. J. Dirkmaat

84. U.S. DEPARTMENT OF ENERGY, Albuquerque Operations Office,

P.O. BOX 5400, Allbuquerque, NM 87115

R. L. Holton

85. U.S. DEPARTMENT OF ENERGY, Chicago Operations Office,

9800 S. Cass Avenue, Argonne, IL 60439

J. L. Hooper

86-87. U.S. DEPARTMENT OF ENERGY, Magnetic Fusion and Nuclear Division, San Francisco Operations Office, 1333 Broadway, Oakland, CA 94612

J. K. Hartman W. L. Lambert

88-92. U.S. DEPARTMENT OF ENERGY, National Materials Programs, Oak Ridge Operations Office, Oak Ridge, TN 37831

E. E. Hoffman

93. AIR FORCE WRIGHT AERONAUTICAL LABS, AFWAL/POOS-3, Wright Patterson $\mathrm{AFB}, \mathrm{OH} 45433$

E. T. Mahefkey

94-277. DOE, TECHNICAL INFORMATION CENTER, Office of Information Services, P.0. Box 62, Oak Ridge, TN 37831

For distribution as shown in DOE/TIC-4500, Distribution Category UC-25 (Materials). 